https://doi.org/10.3126/pragya.v8i01.42425

\title{
Remittances Levels and Trends
}

\section{- Dr. Laxman Singh Kunwar *}

\begin{abstract}
This paper attempts to describe remittances levels and trends at global, regional and national levels. Remittances are being global phenomenon and its impacts have been increased from local level to global economy of world. It has been one of the top issue to analyze and address employment and economy sectors of local to national economy of remittances receiving countries of worlds. The paper is based on secondary sources of information with aim of find level and trends of remittances from national to global levels. Remittances through migration phenomenon has shown the evidences of in reducing poverty levels of remittances receiving regions or countries but the use of remittances pattern differs from one community to other. Nationally and globally volume of remittances has been increased with compared to previous years.
\end{abstract}

Key Words: Remittances, migration, global, regional and national

\section{Introduction}

A remittance refers to money that is sent or transferred to another party. The term is derived from the word remit, which means to send back. Remittances can be sent via a wire transfer, electronic payment system, mail, draft, or check. Remittances can be used for any type of payment including invoices or other obligations. But the term is typically used to refer to money sent to family members back in a person's home country. Payment remittances are money transfers made by people to another party (https://www.investopedia.com/terms/r/remittance.asp). They can be made to satisfy an obligation such as a bill payment or an invoice when someone shops online. But they are most commonly made by a person in one country to someone in another. Most remittances are made by foreign workers to family in their home countries. They may also be payments that are made to a business. The most common way of making a remittance is by using an electronic payment system through a bank or money transfer service such as Western Union. People who use these options are generally charged a fee, but transfers can take as little as ten minutes to reach the recipient (Investopedia, 2020). A foreign remittance is a transfer of money from a foreign worker to their families or other individuals in their home countries

\footnotetext{
* Dr. Kunwar is an Associate Professor of Population Studies, Patan Multiple Campus, TU, Nepal
} 
Remittances play an increasingly large role in the economies of small and developing countries. They are also seen as an important part of disaster relief and often exceed official development assistance (ODA). Remittances are often used as a way to help raise the standard of living for people abroad and help combat global poverty. In fact, since the late 1990s, remittances have exceeded development aid, and in some cases make up a significant portion of a country's gross domestic product (GDP). Remittances are not a new phenomenon in the world, being a normal concomitant of migration which has always been a part of human history. Several European countries, for example Spain, Italy, and Ireland were heavily dependent on remittances received from their emigrants during the 19th and 20th centuries (WB, 2019).

According to the the World Bank $\$ 529$ billion in remittances were sent to low- and middleincome countries in 2018 an increase of $9.6 \%$ over the previous record high of $\$ 483$ billion in 2017. This figure is significantly larger than the $\$ 344$ billion of foreign direct investment in these countries, excluding China, in 2018. If we include high-income countries as well, the total amount of remittances jumps to $\$ 689$ billion, up from $\$ 633$ billion in 2017. On the plus side, remittances are also used to help those living in less developed nations open bank accounts, which helps promote economic development. According to the World Bank, the top remittance recipient countries in 2018 were India with $\$ 79$ billion, followed by China (\$67 billion), Mexico (\$36 billion), the Philippines (\$34 billion), and Egypt (\$29 billion) (WB, 2019).

\section{Objectives}

The objectives of this paper is to introduce remittances and analyze flow of remittances at global, regional and national level.

\section{Data and Methods}

This paper is based on secondary sources of information from World Bank, Asian Development bank, United Nations Development Programs, Nepal Rastrya Bank and other relevant sources related with remittances.

\section{Findings and Discussions}

The findings and discussions are analyzed at global, regional and national levels as per resources are available.

\subsection{Global Scenario}

A remittance is a transfer of money, often by a foreign worker to an individual in their home country. Money sent home by migrants competes with international aid as one of the largest 
financial inflows to developing countries. Workers' remittances are a significant part of international capital flows, especially with regard to labor-exporting countries.

Table 1: Trends of Top Remittances recipient countries, 2012-2017 (in billions of US dollars).

\begin{tabular}{|l|l|l|l|l|l|l|}
\hline Country & 2012 & 2013 & 2014 & 2015 & 2016 & 2017 \\
\hline India & 68.82 & 69.97 & 70.97 & 72.20 & 62.7 & 69 \\
\hline China & 57.99 & 59.49 & 61.49 & 63.90 & 61.0 & 64 \\
\hline Philippines & 24.61 & 26.70 & 27.90 & 29.80 & 29.9 & 33 \\
\hline Mexico & 23.37 & 23.02 & 24.50 & 25,70 & 28.5 & 31 \\
\hline Nigeria & 20.63 & 20,89 & 20.88 & 20.89 & 19.0 & 22 \\
\hline Pakistan & 14.01 & 14.63 & 17.80 & 20.10 & 19.8 & 20 \\
\hline Egypt & 19.24 & 17.83 & 19.83 & 20.40 & 16.6 & 20 \\
\hline Vietnam & 10.0 & 11.0 & 11.80 & 12.30 & 13.4 & 14 \\
\hline Bangladesh & 14.24 & 13.86 & 15.10 & 15.80 & 13.7 & 13 \\
\hline Nepal & 5.88 & 6.01 & 5.29 & 5.8 & 6.40 & 6.60 \\
\hline
\end{tabular}

Source: World Bank, 2017

The above table (1) shows the trends of remittances recipient ten major countries during the period 2012 to 2017. The total volume of remittances by recipient countries have been increased and India has become to most remittance recipient country in the world. Nepal also has been listed among ten remittance recipient country during the same period. In 2018 overall global remittance grew $10 \%$ to US \$689 billion, including US \$528 billion to developing countries. In 2019, in current U.S. dollar terms, the top five remittance recipient countries are projected to be India, China, Mexico, the Philippines, and Egypt (WB, 2018).

Table 2: Estimates and Projections of Remittance Flows to Low- and MiddleIncome Regions

\begin{tabular}{|lccccccc|}
\hline & $\mathbf{2 0 1 0}$ & $\mathbf{2 0 1 6}$ & $\mathbf{2 0 1 7}$ & $\mathbf{2 0 1 8}$ & $\mathbf{2 0 1 9 e}$ & $\mathbf{2 0 2 0 f}$ & $\mathbf{2 0 2 1 f}$ \\
\hline Low and Middle Income & & & & (\$ billions) & & & \\
East Asia and Pacific & $\mathbf{3 4 3}$ & $\mathbf{4 4 4}$ & $\mathbf{4 8 4}$ & $\mathbf{5 2 6}$ & $\mathbf{5 5 1}$ & $\mathbf{5 7 4}$ & $\mathbf{5 9 7}$ \\
Europe and Central Asia & 96 & 128 & 134 & 143 & 149 & 156 & 163 \\
Latin America and the Caribbean & 38 & 44 & 53 & 58 & 59 & 62 & 64 \\
Middle East and North Africa & 56 & 73 & 81 & 89 & 96 & 99 & 103 \\
South Asia & 39 & 51 & 57 & 58 & 59 & 61 & 63 \\
Sub-Saharan Africa & 82 & 111 & 117 & 132 & 139 & 145 & 150 \\
\hline World & $\mathbf{3 2}$ & 38 & 42 & 47 & 49 & 51 & 54 \\
\hline & $\mathbf{4 7 0}$ & $\mathbf{5 8 9}$ & $\mathbf{6 3 4}$ & $\mathbf{6 8 3}$ & $\mathbf{7 0 7}$ & $\mathbf{7 3 9}$ & $\mathbf{7 6 8}$ \\
\hline Low and Middle Income & & & $($ Growth rate, percent) & & \\
East Asia and Pacific & $\mathbf{1 1 . 6}$ & $\mathbf{- 1 . 6}$ & $\mathbf{9 . 1}$ & $\mathbf{8 . 6}$ & $\mathbf{4 . 7}$ & $\mathbf{4 . 2}$ & $\mathbf{4 . 0}$ \\
Europe and Central Asia & 19.9 & -0.5 & 5.1 & 6.8 & 3.8 & 4.7 & 4.5 \\
Latin America and the Caribbean & 5.6 & 0.1 & 22.3 & 8.4 & 1.8 & 4.6 & 4.3 \\
Middle East and North Africa & 2.5 & $\mathbf{7 . 4}$ & 10.8 & 9.6 & 7.8 & 3.8 & 3.6 \\
South Asia & 18.2 & -1.2 & 12.1 & 1.6 & 3.0 & 2.7 & 3.2 \\
Sub-Saharan Africa & 9.4 & -5.9 & 5.8 & 12.7 & 5.3 & 4.1 & 3.6 \\
\hline World & 11.1 & -9.9 & 9.4 & 10.7 & 5.1 & 5.1 & 4.9 \\
\hline
\end{tabular}

Source: World Bank (2017). Notes: $e=$ estimate; $f$ = forecast. Projections for 2019, 2020 and 2021 are based on a low case scenario that assumes unit elasticity of remittances to GDP growth in remittance source countries. 
The above table (2) shows the level of remittances with estimates and projection in low and middle income regions of the world. According the estimates and projections the volume of remittances has been in increasing trends but growth rate has been decreased (8.6 per cent to 4.0 per cent) during the period 2010 to 2021. The major volume of remittance recipient with comparatively high growth region is observed and estimated to East Asia and Pacific regions.

\section{Figure 1: Top Recipients Countries of Remittances, 2019}

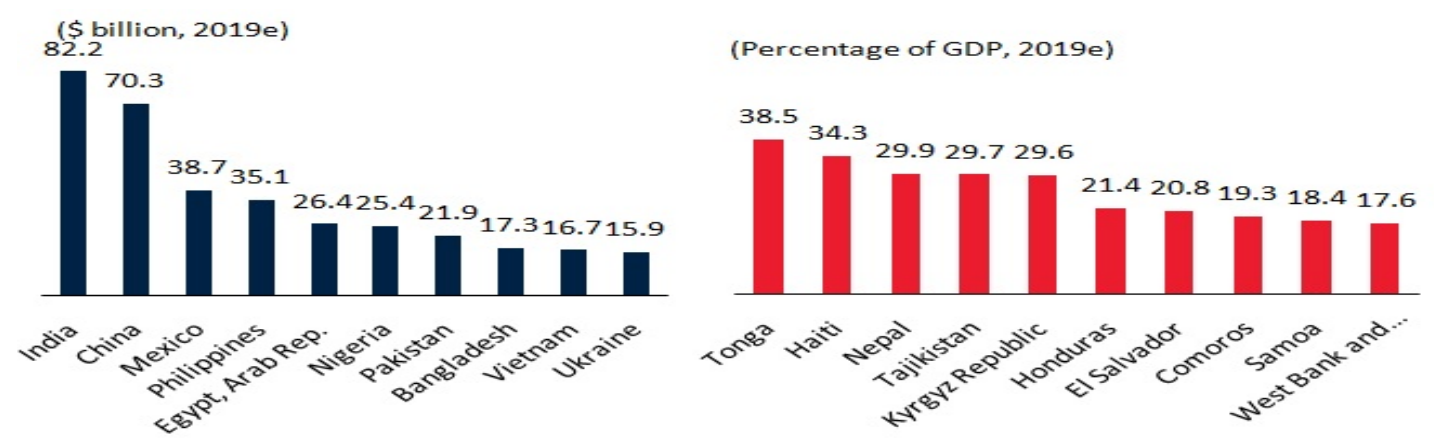

Source: World Bank, 2019

The above fig (1) shows the top ten remittance recipient countries as well as top ten countries with percentage share of remittance in their Gross Domestic Product (GDP). This shows that remittance occupies nearly 30 per cent in GDP of Nepal in 2019. Figure 2: Sources of remittance flows to Low and Middle Income Countries by currency

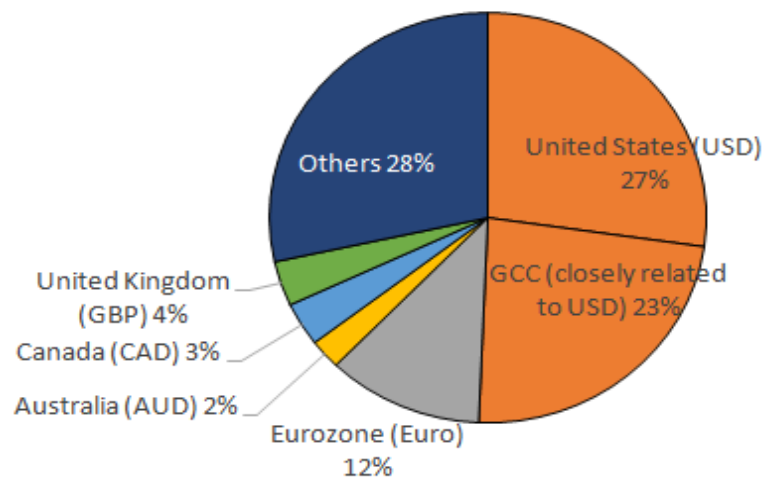

Sources: World Bank-KNOMAD staff estimates. Note: AUD=Australian dollar, $C A D=$ Canadian dollar, $G B P=$ British Pound, $U S D=U S$ dollar

When the currency of a source country depreciates against the US dollar, the value of outward remittances in US dollar terms declines. Approximately a half of remittance flows to LMICs is estimated to originate in countries where US dollar is the main currency or the 
local currency is closely linked to the US dollar (e.g., the Gulf Cooperation Council (GCC) countries); the rest are denominated in other currencies and therefore subject to currency valuation effects. For example, 12 percent of such remittances originated in Euro-zone economies, 4 percent in the United Kingdom, 3 percent in the Russian Federation, 3 percent in Canada, and 2 percent in Australia ( WB, 2019).

\subsection{Regional Scenario}

The slowdown in the growth of remittances in 2019 was sharp in all regions except LAC and SSA (figure, 2). In 2019, Latin America and the Caribbean would see the fastest pace of remittance growth at 7.8 percent due to the continued robustness of the US economy. Remittances would increase moderately in South Asia (5.3 percent), Sub-Saharan Africa (5.1 percent) and East Asia and Pacific (3.8 percent) due to the buoyancy in inflows from the US being offset by slower growth of receipts from the Euro area and the GCC. The growth rate of remittances is likely to remain weak in Middle East and North Africa (3 percent) due to structural changes, such as labor market 'nationalization' and introduction of value added tax, in the GCC countries, and in Europe and Central Asia (1.8 percent) because of lower oil prices and ruble depreciation on outflows from Russia.

Figure 2: Growth of Remittances by Region (\%)

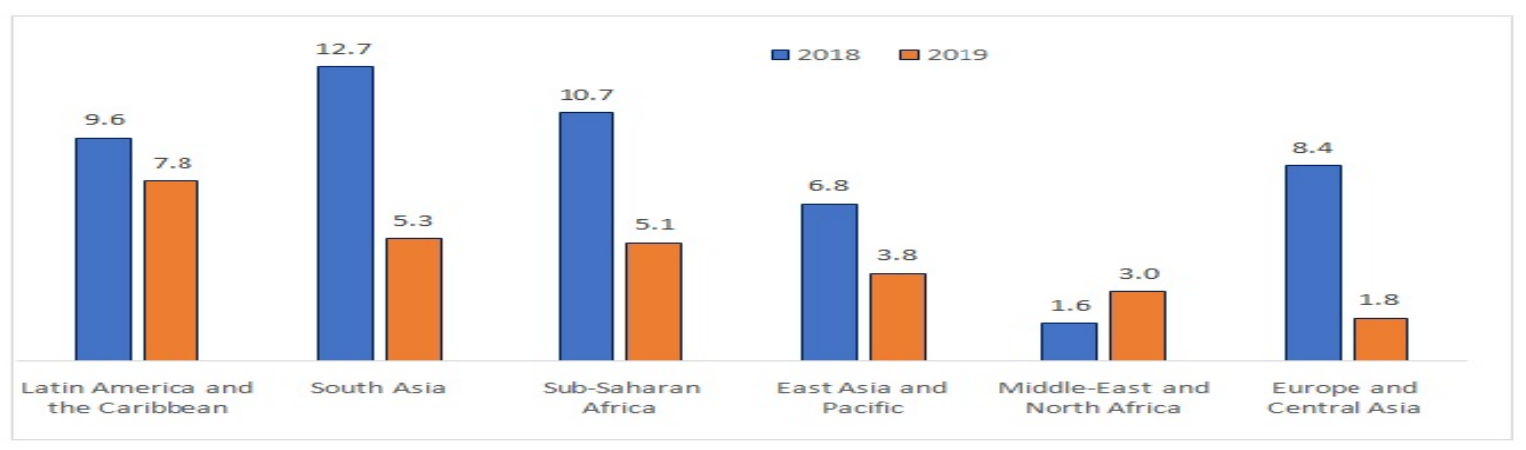

Sources: World Bank, 2020.

Remittance flows to the East Asia and Pacific region grew by 2.6 percent to $\$ 147$ billion in 2019, about 4.3 percentage points lower than the growth rate in 2018. In 2020, remittance flows are expected to decline by 13 percent. Global remittances are projected to decline sharply by about 20 percent in 2020 due to the economic crisis induced by the COVID-19 pandemic and shutdown. Studies show that remittances alleviate poverty in lower- and middle-income countries, improve nutritional outcomes, are associated with higher spending on education, and reduce child labor in disadvantaged households. A fall in remittances affect families' ability to spend on these areas as more of their finances will be directed to solve food shortages and immediate livelihoods needs. (WB, 2020). 


\subsection{National Scenario}

Remittance is an important source of foreign income in Nepal which is a private income and transferred from international migrants to family members in their country of origin. It represents one of the largest sources of financial flows to developing countries. International migrants send their money to the home countries through formal and informal channels. Nepal is 19th largest receiver of remittances with $\$ 8.1$ billion. Nepali migrant workers sent home $\$ 8.1$ billion in 2018, making it the 19th biggest beneficiary of funds sent by migrants around the world. Nepali migrant workers sent home $\$ 8.1$ billion in 2018, making it the 19th biggest beneficiary of funds sent by migrants around the world (WB, 2018).

Fig 3: Remittances in SAARC countries and share in GDP, 2018
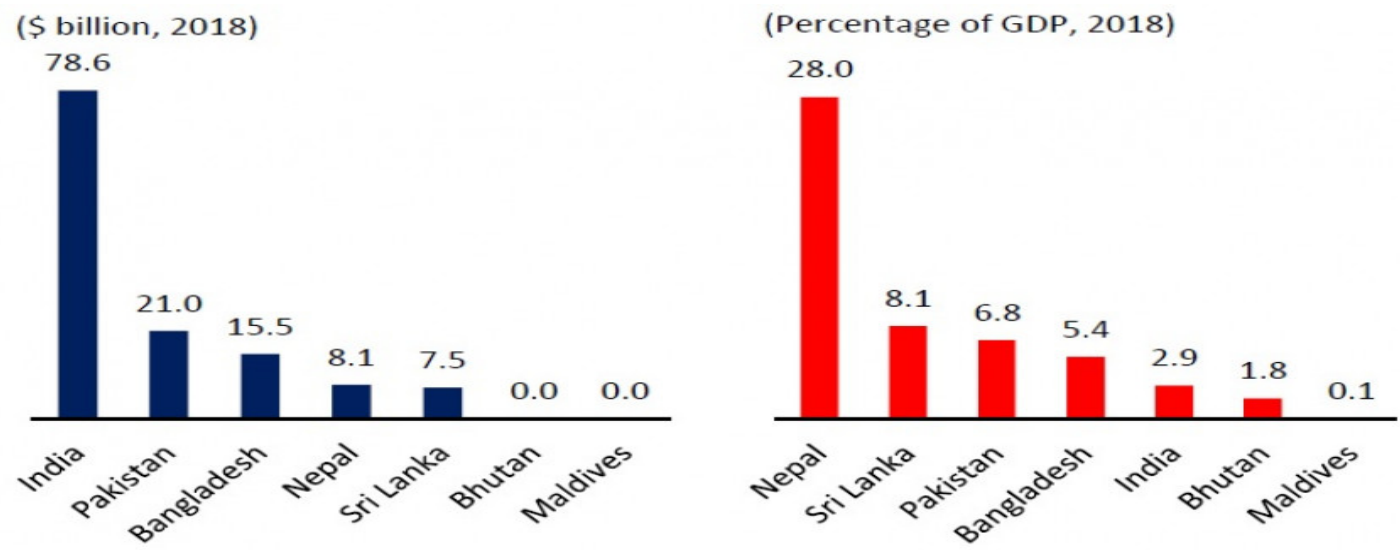

Source: International Organization for Migration, 2019

Data from the Department of Foreign Employment compiled by the International Organization for Migration (IOM) show that the Gulf States of Qatar, United Arab Emirates (UAE), Saudi Arabia and Kuwait are the most popular destinations after India for Nepali migrant workers. Qatar and the UAE alone accounted for 58\% of all the permits issued by the government of Nepal in 2019 allowing migrants to work abroad (IOM, 2019).

In 2018, Nepal ranked fifth highest remittance recipient as a share of GDP amongst all countries in the world. It was the highest recipient in the SAARC countries. The Asian Development Bank describes remittances as the "bedrock" of Nepal's economy, indispensable for Nepal at its present stage of development. Evidently, they increase household income and therefore have positive impacts on the amounts available to spend on education, healthcare and other goods and services. However, there are also negative impacts to migration including on the health and welfare of those who work abroad. Nepal 
is aiming to move from "least developed country" to "developing country" status by 2030, as well as to fulfill the targets in the Sustainable Development Goals by 2030. The National Planning Commission's Roadmap to achieve the SDGs goals (IOM, 2019).

\section{Fig 4: Distribution of Monthly remittances in Nepal (2016/17-2020/21}

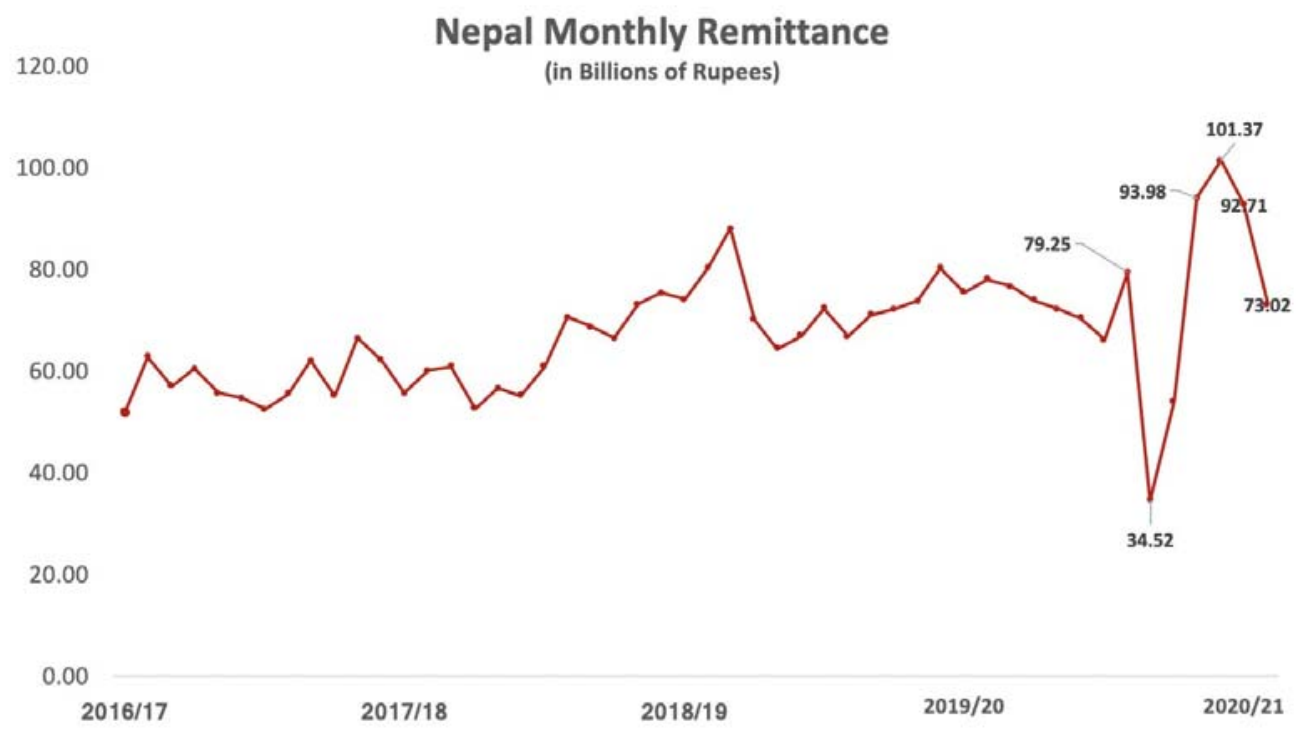

Source: Rastra Bank (NRB), the Status of Remittance Inflow in Nepal, 2021

In the past 10 years, remittance inflow has seen a gradual increase. In the FY 2018/19 alone, Nepal saw a remittance inflow of around NPR 879.3 million (USD 7.8 million). In the first six months of the FY 2019/20, remittance increased by $0.9 \%$ to NPR 447.3 million (USD 4 million) in comparison to the corresponding period of the previous year. As similar to many developing nations Nepal's economy is reliant on remittances. As per Nepal Rastra Bank's report 'The Status of Remittance Inflow in Nepal', Nepal received a total of NPR 879.3 billion (USD 7.8 billion) in remittance in the fiscal year (FY) 2018/19, which is a contribution of $25.4 \%$ to the national GDP of NPR 3.4 trillion (USD 29.8 billion). Besides this, remittance is also the main source of foreign exchange reserves to the country as remittance inflow surpasses the official development assistance received and the total foreign direct investment in Nepal. In FY 2018/19, the official development assistance received was NPR 201.8 billion (USD 1,793 million) and the total inflow from foreign direct Investment was NPR 13 billion (USD 115.5 million) (NRB, 2020).

Figure 5: Total Remittance Received (In million NPR) 


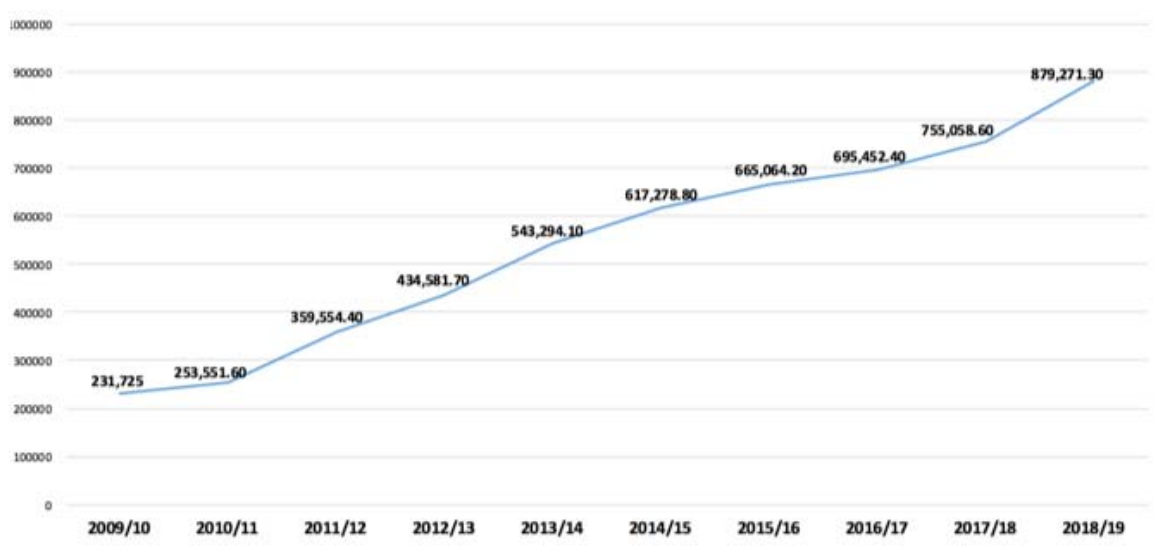

\section{Conclusion}

Remittance trends are increasing globally. The volume of foreign employment is increasing due to globally increasing trends of globalization and liberalization. The global, regional and national data related with remittances are far from exact due to prevailing informal channels of sending and receiving remittances. It was projected that the volume of remittances would decreased due to COVID-19 pandemic. The trends of foreign employment are increasing resulting in rapid growth of remittance received by Nepal. It is found that with the increase in the remittance inflow, there is no further increment of agricultural land. The share of agriculture, forestry and fishing to GDP is found to be decreasing whereas proportion of remittance to GDP is gradually increasing.

\section{References}

International Organization for Migration (2019). Migration in Nepal: A country Profile (Switzerland: IOM).

Khadka, Upasan (2020). Remittances from Nepali Workers Rise (Kathamndu: Nepali Times),

Retrieved from https://www.nepalitimes.com/business/remittances-from-nepali-workers-rise/ on February, 20, 2020.

Nepal Rastra Bank (2021). The Status of Remittance Inflow in Nepal (Kathmandu: Nepal Restra Bank).

World Bank (2019). Migration and Remittances, Retrieved from https://www.worldbank.org/en/topic/labormarkets/brief/migration-and-remittances on $\quad 10$ February, 2019.

World Bank (2020). World Bank Predicts Sharpest Decline of Remittances in Recent, retrieved from https://www.worldbank.org/en/news/press-release/2020/04/22/world-bank-predictssharpest-decline-of-remittances-in-recent-history History on $15^{\text {th }}$ January 2020. https://www.investopedia.com/terms/r/remittance.asp, Retrieved on $10^{\text {th }}$ December 2020. 